\title{
PENGGUNAAN MODEL GROUP TO GROUP EXCHANGE (GGE) UNTUK MENINGKATKAN KEMAMPUAN COMUNICATING
}

\author{
A. Rahmawati' ${ }^{1}$ Mawardi $^{2}$, S. Astuti ${ }^{3}$ \\ ${ }^{1,2,3}$ Pendidikan Guru Sekolah Dasar,Universitas Kristen SatyaWacana, Salatiga \\ auliarahmawati057@gmail.com ${ }^{1}$. \\ mawardi@gmail.com², suhandiastuti15@gmail.com ${ }^{3}$
}

\begin{abstract}
ABSTRAK
Penelitian tindakan kelas ini bertujuanuntukmeningkatkan kemampuan comunicating siswa melalui penerapan model pembelajaran Group To Group Exchange(GGE). Teknik pengumpulan data untuk mengukur kemampuan communicating siswamenggunakan angket. Angket tersebut telah diuji validitas dan reliabilitas menggunakan SPSS 16.0 for windows. Hasil penelitian menunjukkan skor rata-rata kemampuan comunicating pra siklus sebesar 20.36.Pada siklus Imengalami peningkatan menjadi 59.31 dan pada siklus II 75.28. Dengan demikian hasil penelitian ini menunjukkan bahwa ada peningkatan kemampuan comunicating siswa melalui penerapan model pembelajaran $G G E$. Besarnya peningkatan dari siklus I ke siklus II sebesar $27 \%$.
\end{abstract}

Kata kunci:Group To Group Exchange (GGE), KemampuanComunicating

\section{ABSTRACT}

This classroom action research aims to improve students' communicating skills through the application of the Group To Group Exchange (GGE) learning model. Data collection techniques to measure student's skills using questionnaires. The questionnaire has been tested validity aand reliability using SPSS 16.0 for windows. The results showed an average score of pre cycle communicating ability of 20.36. in cycle I increased to 59.31 and at cycle II 75.28. Thus the results of this study indicate that there is improvement of students' communicating skills through the application of GGE learning model. The magnitude of the increase from cycle I to cycle II of $27 \%$.

Keywords: Group To Group Exchange (GGE), Comunicating Capabilities. 


\section{PENDAHULUAN}

Perubahan kurikulum KTSP menjadi kurikulum 2013bertujuan untuk memperbaiki dan meningkatkan mutu pendidikan. Perubahan ini juga di alami oleh guru, guru tidak hanya mengajar saja namun juga melakukan penilaian. Penilaian tersebut bukan hanya penilaian dengan memberikan soal kepada siswa dan memperoleh hasil melainkan penilaian yang mencakup tahap memahami hakikat, cakupan ranah, merancang prosedur penilaian, menyusun instrumen dan melakukan penilaian (Suhandi. Slameto dan Yari, 2017: 37).

Kurikulum 2013 mengatur program yang dilaksanakan di SD/MI dan sedrajat salah satunya mengatur tentang pelaksanaan pembelajaran yang menggunakan tematik. Permendikbud No. 65 tahun 2013 tentang Standar Proses bahwa di SD/MI/SDLB-Paket A juga melaksanakan pembelajaran tematik yang disesuaikan dengan tingkat perkembangan siswa.

Pembelajaran tematik penting dilaksanakan di SD karena siswaa sekolah dasar masih melihat segala sesuatu secara menyeluruh, perkembangan fisik tidak dapat dipisah dengan perkembangan mental, sosial dan emosional (Puspita \& Yuhelman, 2017:33). Maka dari itu peran guru sangat dibutuhkan dalam proses pembelajaran, karena guru merupakan salah satu faktor penentu keberhasilan pembelajaran. Guru mempunyai peran yang sangat penting dalam proses pembelajaran seperti yang dikemukakan oleh (Astuti, 2017: 49) bahwa pentingnya peran guru dalam pembelajaran, tidak akan ada keluaran siswa yang unggul tanpa adanya guru yang bekerja secara profesional.

Kurikulum 2013 lebih menekankan penilaian dari tiga ranah yaitu afektif, psikomotor dan kognitif,yang menekankan pada penggunaan pendekatan saintifik, dimana semua kegiatan pembelajaran dilakukan oleh siswa dengan kata lain pembelajarannya berpusat pada siswa (student center), sedangkan tugas guru sebagai fasilitator dalam pembelajaran. Oleh karena itusiswa dituntut untuk aktif dan diharapkan dapat menerapkan pembelajaran $5 \mathrm{M}$ khususnya pada kemampuan siswa dalam menyampaikan atau meng-komunikasikan dengan siswa lain tentang apa yang sudah JIPP, Volume 2 Nomor 2 Juli 2018 dipelajarinya, melalui kegiatan comunicating siswa mampu melakukan tanya jawab, tukar pendapat dan berbagi informasi. Karena pendidikan tidak hanya mempersiapkan siswa untuk mendapat nilai yang baik, namun juga mempersiapkan siswa yang mampu menyelesiakan masalah dalam kehidupan nyata dengan kemampuan comunicating yang baik.

Kemamapuan comunicating ini sangat penting untuk ditingkan agar siswa dapat saling bertukar informasi dan pendapat, sehingga siswa memperoleh wawasan kedalam pemikiran mereka dan pengetahuan baru. Soelaiman (2007: 112) kemampuan adalah sifat yang dibawa lahir atau dipelajari yang memungkinkan seseorang yang dapat menyelesaikan pekerjaannya, baik secara mental ataupun fisikSardiman (2011: 7) menyatakan bahwaistilah komunikasi berasal dari perkataan "communicare" berarti "berpartisipasi", "memberitahukan", "menjadimilik bersama".

Komunikasi menurut Hutagalung (2007: 65) berasal dari bahasa latin yaitu "communis" yang berarti bersama. Dengan demikian comunicating atau komunikasi dapat diartikan penyebaran informasi, gagasan, ide, pendapat ataupun yang lainnya kepada orang lain.

Penyebaran informasi, gagasan, ide, pendapat ataupun yang lainnya kepada orang lain dapat digolongkan menjadi dua jenis yaitu verbal dan nonverbal. Komunikasi verbal adalah penggunaan bahasa yang telah disusun hingga menjadi sebuah kalimat yang memiliki makna, sedangkan nonverbal adalah bahasa isyarat atau bahasa digunakan untuk meyakinkaan sesuatu yang telah diucapkan.Kemampuan comunicating siswa baik verbal maupun non verbal merupakaan alasan yang mendorong siswa menyam-paikan suatu pesan kepada teman atau guru, comunicatingtersebut terjadiadanya unsurkesengajaan. Ketika dalam pembelajaran dorongancomunicating siswa yang terrencana dapat berupa penyampaian pendapat, diskusi, bertanya dan pemahaman masalah dalam kehidupan nyata. Hal tersebut mampu mendukung siswa dalam pemahaman materi pembelajaran (Noviyanti, 2011: 80).

Kemampuan comunicating membutuhkan dorongan dan arahan dari guru untukagar siswa mengkomunkasikan apa yang siswa 
miliki kepada siswa, guru ataupun orang yang ada disekitarnya sehingga terjadi comunicating yang efektif.Hutagalung, (2007: 68) berpendapat bahwa comunicating yang efektif memiliki tata cara antara lain (1) melihat lawan bicara, (2) suara jelas, (3) ekspresi yang menyenangkan, (4) bahasa yang baik, (5) singkat, jels dan mudah dimengerti. Keberhasilan kemampuan comunicating siswa dapat diukur melalui indicator kemampuan comunicating.

Indikator comunicating menurut Hutagalung (2007: 68) berdasarkan motif dan comunicating yang efektif maka dapat disimpulkan menjadi dua yang pertama adalah kemampuan berkomunikasi verbal meliputi (1) melakukan diskusi, (2) mempresentasikan hasil diskusi, (3) menyampaikan pendapat, (4) menjawabpertanyaan,

menuliskanhasilakhirdiskusi, (6)tata bahasa yang baik, (7) pembicaraansingkat, jelasdan mudah dimengertidan (8) suaraterdengar jelas. Kemudian yang kedua adalah kemampuan komunikasi nonverbal meliputi(1)melihatlawan bicara, ekspresiwajahyangramah, dan (3) gerakantanganyang sesuai dengan katakatayangdiucapkan. Indikator tersebut digunakan peneliti untuk mengetahui kondisi awal kemampuan comunicating siswa.

Sesuai dengan Kurikulum 2013, Comunicating merupakan salah satu unsur dalam pendekatan saintifik, dimana dalam pembelajaran tematik pendekatan saintifik haruslah digunakan dalam pembelajaran. Menurut Rusman (2012: 254) pembelajaran tematik merupakan model pembelajaran terpadu yang memungkinkan siswa baik individu maupun kelompok aktif dalam mengikuti pembelajaran.Dengan demikian pembelajaran harus memberikan makna yang utuh kepada siswa yang tercermin pada berbagai tema yanag tersedia (Kurniawati dan Wakhyudin, 2014: 60).

Pendekatan saintifik berkaitan erat dengan metode saintifik yang melibatkan kegiatan pengamatan atau observasi untuk perumusan atau pengumpulan datasecara langsung yang membutuhkan kerjasama,baik sesama anggota kelompok maupun dengan anggota masyarakat. Pendekatan ini meliputi (1) Mengamati, (2) Menanya, (3) Mencoba atau Mengumpulkan Informasi, (4) Menalar atau Asosiasi dan (5) Membantuk jejaring atau Melakukan Komunikasi. Melalui pembelajaran saintifik diharapkan siswa memiiliki kemampuan berkomunikasi atau communicating melalui kegiatan mengamati, menanya, mengumpulkan informasi dan menalar.

Berdasarkan hasil observasi yang dilakukan di SDN Mangunsari 03 menunjukkan belum sesuai dengan harapan. Kemampuan comunicating siswa masih rendah. Guru belum menerapkan modelmodel pembelajaran yang mampu mewadahi kebutuhan, melatih dan mengembangkan kemampuan comunicating siswa. Pembelajaran yang telah berlangsung masih menggunakan ceramah dan penugasan terlihat pada saat pembelajaran dikelas, siswa cenderung diam ketika diminta menjawab pertanyaan dari guru, siswa dalam belajar kelompok juga kurang mampu berdiskusi, menyampaikan hasil dari materi yang sudah dipelajarinya kepada siswa lain dan terlihat jelas kurang adanya rasa percaya diri dalam presentasi maupun mengemukakan pendapat dengan hasil uji statistik deskriptif dapat dilihat pada tabel 1 .

Tabel 1. Descriptive Statistics Kemampuan Comunicating Pra Siklus

\begin{tabular}{cccccc}
\hline & N & Min & Max & Mean & Std. Deviation \\
\hline $\begin{array}{c}\text { Pra } \\
\text { Siklus }\end{array}$ & 38 & 16 & 30 & 20.36 & 3.32 \\
\hline
\end{tabular}

Tabel 1 ini merupakan hasil dari pengisian indikator kemampuan comunicating siswa SDN Mangunsari 03 sebagai data awal penelitian. Berdasarkaan tabel 1dapat dilihat bahwa dengan jumlah $(\mathrm{N})$ sebanyak 38 siswa pada pra siklus memperoleh skor rata-rata 20.36 dengan nilai terrendah 16 , nilai tertinggi 30 dan standar deviasinya seberar 3.32. Hasil uji statistik deskriptif dapat diperjelas pada tabel 2. 
Tabel 2. Hasil Angket Kemampuan Comunicating Pra Siklus

\begin{tabular}{cccc}
\hline Kriteria & $\begin{array}{c}\text { Rentang } \\
\text { Nilai }\end{array}$ & $\begin{array}{c}\text { Fre- } \\
\text { kuensi }\end{array}$ & $\begin{array}{c}\text { Presen- } \\
\text { tase }\end{array}$ \\
\hline Sangat Baik & $38-44$ & - & - \\
\hline Baik & $29-37$ & 1 & $3 \%$ \\
\hline Cukup & $20-28$ & 19 & $50 \%$ \\
\hline Kurang Baik & $11-19$ & 18 & $47 \%$ \\
\hline Total & & 38 & $100 \%$ \\
\hline
\end{tabular}

Tabel 2 berikut menunjukkan tingkat kemampuan comunicating siswa kelas 4 SDN Mangunsari 03. Berdasarkan table 2 menunjukkan 18 siswa atau $47 \%$ pada kriteria kurang, 19 siswa atau 50\%pada kriteria cukup danhanya 1 siswa atau sebesar $3 \%$ pada kriteria baik.

Hasil data awal di atas menunjukkan bahwa kemampuan comunicating siswa dalam pembelajaran tematik belum optimal. Hal ini disebabkan karena belum adanya penerapan suatu model pembelajaran yang inovatif.Dalam pembelajaran yang sudah berlangsung masih didominasi penggunaan metode ceramah dan penugasan sehingga membuat siswa bosan dan tidak aktif yang mengakibatkan kemampuan comunicating siswa rendah. Oleh karena itu perlu dilakukan tindakan perbaikan.

Alternatif yang dapat digunakan adalah penerapan model pembelajaran yang mampu mendorong kemampuan comunicating dan siswa mampu terlibat aktif dalam pembelajaran. Hal ini dikarenakan model pembelajaran merupakan suatu setrategi yang digunakan guru berupa gagasan atau ide untuk meningkatkan motivasi belajar siswa (Mawardi \& Sari, 2015: 82). Salah satunya adalah dengan menerapkan model pembelajaran Group To Group Exchange (GGE).

Murni,Yusra T dan Solfitri (2010:4) berpendapat bahwa Group to Group Exchange $(G G E)$ adalah salah satu metode belajar aktif yang menuntut siswa untuk berfikir tentang apa yang dipelajari, kemudian berkesempatan untuk berdiskusi dengan teman, bertanya dan membagi pengetahuan yang diperoleh kepada yang lainnya.

Selanjutnya, Silberman yang dikutip oleh(Dharyani, 2010: 176) menyatakan bahwa GGEadalah model pembelajaran pemberian tugas yang berbeda pada masing-masing kelompok yang kemudian masing-masing kelompok mengajarkan apa yang dipelajarinya kepada kelompok lain melalui presentasi. Prayogo,Silviana (2010: 434) berpendapat bahwa model pembelajaran $G G E$ adalah suatu format diskusi dalam kelompok dan dengan pemberian tugas yang berbedabeda.

Model pembelajaran ini memanfaat-kan kelompok belajar untuk memaksimalkan kemampuan comunicating siswa, dalam pembagian kelompok dibuat secara heterogen agar tidak adanya penguasaan dalam proses pembelajran pada salah satu kelompok. Model belajarGroup to Group Exchange masingmasing kelompok diberi tugas untuk mempelajari satu topik materi, siswa dituntut untuk menguasai materi karena setelah kegiatan diskusi kelompok berakhir, siswa akan bertindak sebagai guru bagi siswa lain dengan mempresentasikan hasil diskusinya kepada kelompok lain di depan kelas. Group to Group Exchange memberi kesempatan kepada siswa untuk bertindak sebagai guru bagi siswa lainnya.

Setiap model pembelajaran tentunya memiliki kelebihan dan kelemahan, begitupula dengan model pembelajaran Group To Group Exchang (GGE) ini. Silberman (2009: 178) menjelaskan kelebihan dan kekurangan model pembelajaran Group To Group Exchang (GGE), kelebihan dari model tersebut meliputi (1) Membiasakan siswa bekerja sama menurut paham demokrasi, memberikan kesempatan mengembangkan sikap musyawarah dan tanggung jawab, (2) Menumbuhkan rasa kompetitif yang sehat, (3) Melatih siswa melaksanakan tugas kewajiban yang patuh peraturan. Kemudian model ini juga memiliki kekurangan yaitu sebagai berikut (1) Sulit menyusun kelompok 
heterogen,siswa merasa tidak enak dengan anggota kelompok yang dipilih guru, (2) Dalam kerja kelompok terkadang pemimpin kelompok sulit menjelaskan dan mengadakan pembagian kerja, anggota kelompok kadangkadang tidak mematuhi tugas yang diberikan oleh pemimpin kelompok dan dalam belajar kelompok sering tidak terkendali sehingga menyimpang dari rencana yang telah ditentukan.

Untuk mengantisipasi kelemahan model pembelajaran tersebut peneliti menggunakan poin bintang. Siswa yang tidak mematuhi tugas, tidak aktif dalam diskusi kelompok, tidak mau bertanya atau tidak memperhatikan maka akan mengurangi bintang yang diperoleh kelompok. Begitupula sebaliknya jika siswa akatif dalam kelompok maka akan menambah poin bintang yang sudah diperoleh.

Model pembelajaran $G G E$ ini telah diteliti oleh beberapa peneliti lainnya, temuan bahwa model ini mampu meningkatkan hasil belajar siswa dalam berbagai mata pelajaran. Berdasarkan ciri khas dari model $G G E$ ini yang menuntut siswa belajar aktif, mandiri (mengumpulkan informasi dari berbagai sumber), diskusi, dan bertukar informasi maka dalam penelitian ini menunjukkan bahwa model GGE ini tidak hanya mampu meningkatkan hasil belajar siswa, namun melalui penerapan langkat-langkah model $G G E$, arahan dari guru, dan penambahan sumber belajar, siswa mampu meningkatkan kemampuan comunicating yang dimilikinya yang berpengaruh terhadap hasil belajar siswa.

Tujuan dari penelitian ini adalah meningkatkan kemampuan comunicating siswa melalui penerapan model pembelajaran Group To Group Exchange pada siswa kelas 4 SDN Mangunsari 03, Salatiga semester II tahun ajaran 2017/2018.

\section{METODE PENELITIAN}

Jenis penelitian ini digolongkan dalam penelitian deskriptifmenggunakan CAR (Class Room Action Research) atau Penelitian Tindakan Kelas. Penelitian Tindakan Kelas adalah kegiatan penelitian ilmiah yang dilakukan secara rasional, sistematis dan empiris reflektif terhadap berbagai tindakan yang dilakukan oleh guru atau dosen (tenaga pendidik), kolaborasi (tim peneliti) yang JIPP, Volume 2 Nomor 2 Juli 2018 sekaligus sebagai peneliti, sejak disusunnya suatu perencanaan sampai penilaian terhadap tindakan nyata di dalam kelas yang berupa kegiatanbelajar mengajar, untuk memperbaiki dan meningkatkan kondisi pembelajaran yang dilakukan (Iskandar, 2012: 21).

Penelitian tindakan kelas ini dilakukan dengan 4 tahap yaitu perencanaan, pelaksanaan, observasi dan refleksi (Arikunto , 2013:16). Prosedur ini tidak hanya berlangsung satu kali, tetapi dilakukan beberapa kali hingga mencapai tujuan yang diharapkan.

Penelitian dilaksanakan di kelas 4 SDN Mangunsari 03, Salatiga semester II tahun ajaran 2017/2018, dengan total siswa 38 terdiri dari 23 siswa laki-laki dan 15 siswa perempuan. Tempat penelitian yaitu di SDN Mangunsari 03 yang terletak di kelurahan Mangunsari kecamatan Sidomukti kota madya Salatiga Jawa Tengah. Waktu pelaksanaan diawalidengan pembuatan proposalpada bulanNovember -Desember dan penyusunan instrument pada Januari- Maretminggu, selanjutnya

dilaksanakanpengumpulandatapada bulan April 2018 minggu ke-1 dan 2.

Data penelitiandiperoleh melalui hasil observasi, angket kemampuan comunicating dan tes evalusai menggunakan: (1) lembar observasi kegiatan guru dan siswa dalam penerapan model pembelajaran Group To Group Exchange, (2) angket kemampuan comunicating siswa dalam penerapan model Group To Group Exchange, (3) soal tes evaluasi sebagai dampak dari adanya peningkatan kemampuan comunicating.

Penelitian ini fokus utamanya adalah peningkatan kemampuan comunicating siswa yang di ukur menggunakan angket. Angket tersebut sudah melalui tahap uji validitas dan reliabilitas. Uji validitas dan reliabilitas tersebut dilakukan di SD Sidorejo Lor 03.

Sugiyono (2010:267) mengatakan bahwa validitas merupakan ketepatan antara data yang akan diteliti dengan data yang dapat dilaporkan oleh penelitian. Valid atau tidaknya alat ukur digunakan pendekatan secara statistika, melalui nilai koefisien korelasi skor butir pertanyaan dengan skor total butir pertanyaan, apabila koefisiennya lebih dari atau sama dengan 0.30 maka pertanyaan tersebut dikatakan valid, apabila kurang dari 0.30 maka pertanyaan tersebut dikatakan tidak valid. Berdasarkan ketentuan 
uji validitas yang disampaikan oleh Sugiyono (2010:267), uji validitas yaang telah dilaakukan menunjukkan hasil 4 butir pertanyaan yang tidak valid atau $<0,30$ dari keseluruhan 25 butir pertanyaan.

Sugiyono, (2010:354) menyatakan bahwa uji reliabilitas dilakukan untuk mengetahui seberapa konsisten alat ukur jika digunakan lebih dari satu kali. Uji reliabilitas ini dilakukan untuk mengetahui apakah alat ukur yang sudah dibuat dalam bentuk angket ini dapat di gunakan berulang-ulang kali dan dapat di andalkan, maka untuk mengetahui itu dapat digunakan pendekatan secara statisika melalui koefisien reliabilitas. Jika reliabilitas suatu alat ukur lebih dari 0.60 maka pertanyaan yang sudah dibuat dapat digunakan berulang-ulang dan dapat dikatakan handal. Berdasarkan uji reliabilitas yang disampaikan oleh Sugiyono (2010:354), menunjukkan bahwa alat ukur yang digunakan sudah mencapat kriteria yaitu lebih dari 0.60. Adapun hasil uji reliabilitas Cronbach's Alpha menunjukkan angka 0.838 dari 25 butir pertanyaan.

Adapun indikator keberhasilan dalam penelitian ini adalah terjadinya peningkatan kemampuan comunicating siswa dalam pembelajaran $\geq 25 \%$ dan peningkatan hasil belajar siswadengan ketuntasan $\geq 70 \%$ jumlaah siswa yang tuntas dengan kriteria KKM 75.

\section{HASIL DAN PEMBAHASAN}

\section{Hasil Penelitian}

Perencanaan dalam penelitian inidiawali dengan penyusunan RencanaPelaksanaan Pembelajaran (RPP), bahan ajar, lembar observasi, angket kemampuan comunicating siswa, tes evaluasi dan menyiapkan sarana prasarana yang digunakan dalam pembelajaran.

Pelaksanaan tindakansiklus I kegiatan awalnya adalah berdoa, presensi dan mena- nyakan kabar siswa, menyanyikan lagu Indonesia Raya, apersepsi, tanya jawab menyampaikan tujuan dan topik pembelajaran.

Kemudian kegiatan inti dilakukan penerapan model pembelajaran Group To Group Exchange (GGE), pertama membagi siswa dalam kelompok, guru menjelaskan tugas dalam belajar kelompok, siswa setiap kelompok mendapatkan meteri yang berbedabeda. Setelah siswa atau setiap kelompok sudah memperoleh materi yang berbeda-beda kemudian siswa dengan bimbingan guru menyusun rumusan masalah sesuai dengan materi yang diproleh setiap kelompok. Setelah merumuskan masalah siswa diminta mengumpulkan informasi dari buku, guru, internet dan lain sebagainya kemudian di diskusikan. Selanjutnya siswa diminta mencatat dan membuat laporan berdasarkan informasi yang sudah diperoleh, kemudian laporan tersebut dikumpulkan. Siswa mambuat media presentasi dan mempresentasikannya. Dalam semua kegiaatan yangdilakukan siswa akan memperoleh bintang, jadi antar kelompok melakukan sebaik mungkin untuk memperoleh bintang yang banyak.

Pada akhir kegiatan peneliti menanyakan tentang pemahaman siswa apakah siswa paham atau tidak dengaan kegiatan pembelajaran, kemudian menyimpulkan, refleksi, tes evaluasi dan pengisian angket yang diberikan kepada siswa pada akhir siklus.

Observasi yang telah dilakukan sebagai data hasil aktifitas guru dan siswa dalam penerapan model pembelajaran Group To Group Exchange (GGE), kemudian dilakukan refleksi untuk mengetahui keberhasilan, kelebihan dan kelemahan pembelajaran. Berikut merupakan hasil observasi kegiatan guru pada siklus I dan II dapat dilihat pada tabel 3.

Tabel 3. Hasil Aktivitas Guru dalam Pembelajaran Tema 7 Indahnya Keragaman di Negeriku Pada Siklus I dan Siklus II

\begin{tabular}{ccccc}
\hline Skor Penilaian & \multicolumn{2}{c}{ Siklus I } & & Siklus II \\
\cline { 2 - 5 } & $\begin{array}{c}\text { Fre- } \\
\text { kuensi }\end{array}$ & $\begin{array}{c}\text { Persen- } \\
\text { tase }\end{array}$ & $\begin{array}{c}\text { Fre- } \\
\text { kuensi }\end{array}$ & Jum-lah \\
\hline 100 & 14 & $\mathbf{8 7 \%}$ & $\mathbf{1 6}$ & $\mathbf{1 0 0 \%}$ \\
\hline 0 & 2 & $13 \%$ & 0 & $0 \%$ \\
\hline
\end{tabular}


Tabel 3berikut menunjukkan hasil observasi aktivitas guru kelas 4 SDN Mangunsari 03 pada siklus I dan siklus II. Berdasarkan di atas menunjukkan hasil bahwa pada siklus I aktivitas guru dalam pembelajaran dengan menggunakan model pembelajaran Group To Group Exchange keseluruhan yang sudah dilakukan adalah 14 atau $87 \%$ sudah dilakukan. Ada 2 kegiatan yang belum dilaksanakan guru atau sebesar $13 \%$.

Pada siklus II aktivitas guru dalam pembelajaran dengan menggunakan model pembelajaran Group To Group Exchange keseluruhan yang sudah dilakukan adalah 16 atau $100 \%$ sudah dilakukan. Keseluruhan kegiatan sudah dilakukan oleh guru dan peneliti sebaik mungkin.

Data di atas menunjukkan adanya peningkatan aktivitas guru dari siklus I ke siklus II. Pada awalnya persentase pada siklus I adalah $87 \%$, lalu meningkat menjadi $100 \%$. Peningkatan tersebut dapat diperjelas pada gambar 1 .

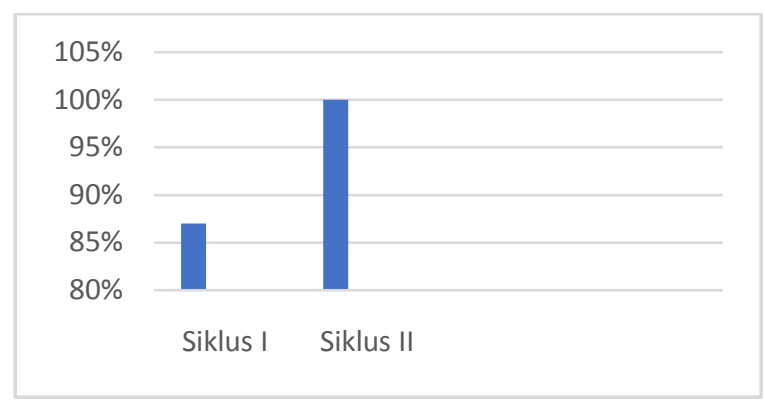

Gambar 1. Grafik Aktivitas Guru dalam Pembelajaran Tema 7 Indahnya Keragaman di Negeriku pada Siklus I dan Siklus II

Kemudian guru melakukan observasi aktifitas siswa dalam pembelajaran melalui penerapan model pembelajaran Group To
Group Exchange (GGE). Berikut merupakan hasil observasi siswa dapat dilihat pada tabel 4.

Tabel 4. Hasil Aktivitas Siswa dalam Pembelajaran Tema 7 Indahnya Keragaman di Negeriku pada Siklus I dan Siklus II

\begin{tabular}{ccccc}
\hline Skor Penilaian & \multicolumn{2}{c}{ Siklus I } & \multicolumn{2}{c}{ Siklus II } \\
\cline { 2 - 5 } & $\begin{array}{c}\text { Fre- } \\
\text { kuensi }\end{array}$ & Persen-tase & Fre-kuensi & $\begin{array}{c}\text { Jum- } \\
\text { lah }\end{array}$ \\
\hline 100 & $\mathbf{1 2}$ & $\mathbf{8 0 \%}$ & $\mathbf{1 5}$ & $\mathbf{1 0 0 \%}$ \\
\hline $\mathbf{0}$ & $\mathbf{3}$ & $\mathbf{2 0 \%}$ & $\mathbf{0}$ & $\mathbf{0 \%}$ \\
\hline
\end{tabular}

Berdasarkan tebel 4 menunjukkan hasil bahwa pada siklus I aktivitas siswa dalam pembelajaran dengan menggunakan model pembelajaran Group To Group Exchange keseluruhan yang sudah dilakukan adalah 12 atau $80 \%$ sudah dilakukan. Ada 3 kegiatan yang belum dilaksanakan guru atau sebesar $20 \%$.

Pada siklus II aktivitas guru dalam pembelajaran dengan menggunakan model pembelajaran Group To Group Exchange keseluruhan yang sudah dilakukan adalah 15 atau $100 \%$ sudah dilakukan. Keseluruhan kegiatan sudah dilakukan oleh guru dan peneliti sebaik mungkin.

Berdasarkan data di atas maka dapat dilihat adanya peningkatan aktivitas guru dari siklus I ke siklus II. Pada awalnya persentase pada siklus I adalah $80 \%$, lalu meningkat menjadi $100 \%$ karena semua langkah pembelajaran menggunakan model Group To Group Exchangetelah dilakukan semua. Peningkatan tersebut dapat diperjelas pada gambar 2 . 


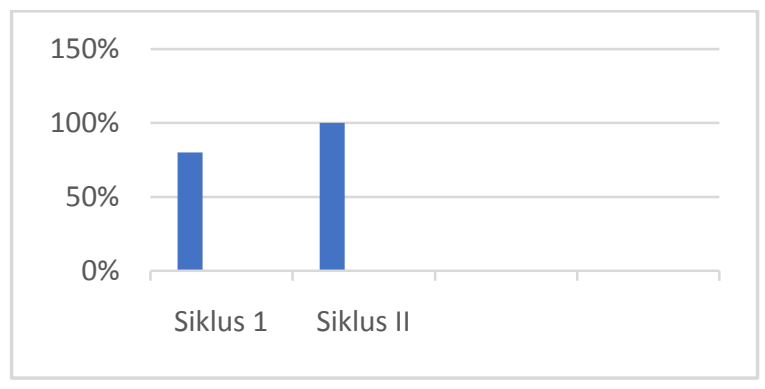

Gambar 2. Grafik Aktivitas Siswa dalam Pembelajaran Tema 7 Indahnya Keragaman di Negeriku pada Siklus I dan Siklus II

Data kemampuan comunicating siswa diperoleh dari pengisian lembar angket yang dibagikan kepada siswa, lembar angket siswa tersebut berisikan 20 indikator kemampuan comunicating yang diambil dari beberapa ahli yaitu sebagai berikut (1) ikut serta dalam pembagian kelompok, (2) bergabung dalam kelompok, (3) ikut serta dalam diskusi kelompok, (4) memahami materi diskusi, (5) memahami materi yang akan di presentasikan, (6) mempresentasikan hasil diskusi, (7) memiliki pendapat, (8) telah berpendapat, (9) menghargai pendapat teman, (10) mampu membuat pertanyaan, (11) mampu menjawab pertanyaan, (12) telah menjawab pertanyaan dengan bahasa yang baik dan benar, (13) menulis materi yang dijelaskan/dipresentasi-kan taman, (14) telah menggunakan bahasa yang baik dan benar pada saat berbicara maupun presentasi, (15) telah melakukan presentasi/ menjelaskan dengan jelas, (16) telah melakukan presentasi/menjelaskan dengan mudah dan dapat dimengerti, (17) berbicara dengan jelas, lantang dan keras, (18) tersenyum pada saat presentasi, (19) menggunakan ekspresi wajah yang ramah, (20) menggunakan gerakan tangan sesuai dengan apa yang saya ucapkan.

Berikut merupakan hasil dari pengisian angket kemampuan comunicating mulai dari pra siklus, siklus I hingga siklus II setelah dilakukan uji statistik deskriptif dapat dilihat pada tabel 5 .

Tabel 5. Descriptive Statistics Kemampuan ComunicatingPra Siklus, Siklus I dan Siklus II

\begin{tabular}{|c|c|c|c|c|c|c|}
\hline & $\mathrm{N}$ & $\begin{array}{c}\text { Instru } \\
\text {-men }\end{array}$ & Min & $\begin{array}{c}\text { Ma } \\
\text { x }\end{array}$ & Mean & Std. Devia-tion \\
\hline $\begin{array}{l}\text { Pra } \\
\text { Sik- } \\
\text { lus }\end{array}$ & 38 & $\begin{array}{c}11 \\
\text { Indik } \\
\text { ator }\end{array}$ & 16 & 30 & 20.36 & 3.32 \\
\hline $\begin{array}{l}\text { Sik- } \\
\text { lus I }\end{array}$ & 38 & $\begin{array}{c}20 \\
\text { Indik } \\
\text { ator }\end{array}$ & 51 & 68 & 59.31 & 5.13 \\
\hline $\begin{array}{c}\text { Sik- } \\
\text { lus } \\
\text { II }\end{array}$ & 38 & $\begin{array}{c}20 \\
\text { Indik } \\
\text { ator }\end{array}$ & 70 & 80 & 75.28 & 2.62 \\
\hline
\end{tabular}

Tabel 5 ini merupakan hasil dari pengisian indikator kemampuan comunicating siswa SDN Mangunsari 03 sebagai data pra siklus, siklus I dan siklus II.

Berdasarkan tabel 5 terlihat adanya peningkatan kemampuan comunicating pada setiap siklus, dilihat dari rata-rata awal hanya mencapai 20.36 kemudian pada siklus
I meningkat menjadi 59.31 dan pada siklus II mengalami peningkatan menjadi 75.28. Nilai deviasi pra siklus menunjukkan angka 3.32, pada siklus I sebesar 5.13 dan pada siklus II menjadi 2.62 .

Hasil uji statistik deskriptif di atas dapat diperjelas pada tabel 6 . 
PPs Universitas Pendidikan Ganesha

Tabel 6. Hasil Angket Kemampuan Comunicating Pra Siklus, Siklus I dan Siklus II

\begin{tabular}{llllllll}
\hline No & Kriteria & Pra Siklus & Siklus I & & Siklus II \\
\cline { 2 - 7 } & Jum lah & $\begin{array}{l}\text { Persen } \\
\text { tase }\end{array}$ & $\begin{array}{l}\text { Jum } \\
\text { lah }\end{array}$ & $\begin{array}{l}\text { Persen } \\
\text { Tase }\end{array}$ & $\begin{array}{l}\text { Jum } \\
\text { lah }\end{array}$ & $\begin{array}{l}\text { Persen } \\
\text { tase }\end{array}$ \\
\hline 1 & $\begin{array}{l}\text { Sangat } \\
\text { Baik }\end{array}$ & 0 & $0 \%$ & 2 & $5 \%$ & 38 & $100 \%$ \\
\hline 2 & Baik & 1 & $3 \%$ & 36 & $95 \%$ & 0 & $0 \%$ \\
\hline 3 & Cukup & 19 & $50 \%$ & 0 & $0 \%$ & 0 & $0 \%$ \\
\hline 4 & Kurang & 18 & $47 \%$ & 0 & $0 \%$ & 0 & $100 \%$ \\
\hline Jumlah & 38 & $100 \%$ & 38 & $100 \%$ & 38 & 0 \\
\hline
\end{tabular}

Berdasarkan tabel 6 diatas menunjukkan pada pra siklus tidak ada siswa yang mampu mencapai kriteria sangat baik atau dengan persentase $0 \%$, siswa yang mampu mencapai kriteria baik sebanyak 1 siswa atau 3\% saja, pada pra siklus ini siswa yang mencapai kriteria cukup berjumlah 19 siswa atau 50\%, dan 18 siswa atau sebanyak $47 \%$ berada dalam kriteria kurang. Dengan adanya data pra siklus yang menunjukkan rendahnya kemampuan comunicating siswa maka dilakukan tindakan siklus I dengan penerapan model pembelajaran Group To Group Exchange dengan perolehan hasil siswa yang mampu mencapai kriteria sangat baik sebanyak 2 siswa dengan rentang nilai 66-80 atau hanya sebesar 5\%, siswa yang mampu mencapai kariteria baik hampir semua siswa yaitu sebanyak 36 siswa dengan rentang nilai 51-65 atau sebesar 95\% dari jumlah keseluruhan 38 siswa, maka tidak ada satupun siswa yang berapada pada kriteria cukup dan kurang. Melihat adanya hasil pada siklus I siswa yang berada pada kriteria sangat baik hanya terdapat $5 \%$ maka dilakukanlah tindakan pada siklus II yang memperoleh hasil semua siswa mampu berada pada kriteria sangat baik dengan rentang nilai 66-80.

berdasarkan tabel 4 maka dapat disimpulkan kemampuan comunicating siswa dari hasil angket yang diisi oleh siswa mulai dari pra siklus, siklus I sampai dengan siklus II menunjukkan adanya peningkatan kemampuan comunicating siswa kelas 4 SDN Mangunsari 03. Peningkatan tersebut dapat diperjelas dengan gambar 3:

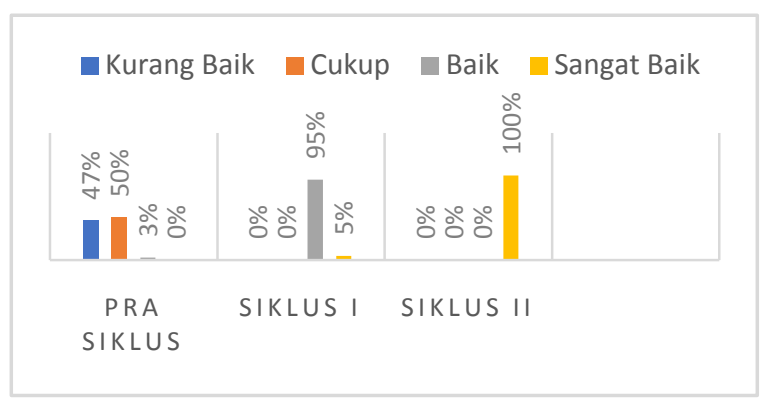

Gambar 3. Grafik Peningkatan Kemampuan Comunicating Siswa Pada Pra Siklus, Siklus I, dan Siklus II

Kemampuan comunicating siswa melalui penerapan model pembelajaran Group To Group exchange sudah mampu dibuktikan peningkatannya, peningkatan kemampuan comunicating berpengaruh terhadap hasil belajar siswa kelas 4 SDN Mangunsaro 03. Peningkatan hasil belajar siswa dilihat dari tes evaluasi yang berbentuk pilihan ganda yang berjumlah 35 butir soal pada setiap siklus yang berpedoman pada Taksonomu Bloom mulai dari ranah $\mathrm{C} 1$ sampai dengan $\mathrm{C} 3$. Hasil tes evaluasi untuk meningkatkan hasil belajar siswa pada kelas 4 siklus I dan siklus II dapat dilihat pada tabel 7 . 
Tabel 7. Nilai Tes Siklus I dan Siklus II Tema 7 Indahnya Kragaman di Negeriku

\begin{tabular}{|c|c|c|c|c|c|}
\hline \multirow[t]{2}{*}{ No } & \multirow[t]{2}{*}{ Ren-tang Nilai } & \multicolumn{2}{|l|}{ Siklus I } & \multicolumn{2}{|l|}{ Siklus II } \\
\hline & & Jum-lah & $\begin{array}{l}\text { Pre } \\
\text { sen } \\
\text { tase }\end{array}$ & Jum-lah & $\begin{array}{l}\text { Per } \\
\text { sen } \\
\text { tase }\end{array}$ \\
\hline 1 & $0-25$ & 0 & & 0 & $0 \%$ \\
\hline 2 & $26-50$ & 0 & & 0 & $0 \%$ \\
\hline 3 & $51-75$ & 24 & $63 \%$ & 1 & $3 \%$ \\
\hline 4 & $76-100$ & 14 & $37 \%$ & 37 & $97 \%$ \\
\hline Jumlah & & 38 & $100 \%$ & 38 & $100 \%$ \\
\hline KKM & & 75 & & 75 & \\
\hline Rata-rata & & 75.86 & & 79.14 & \\
\hline Nilai Tertinggi & & 82 & & 84 & \\
\hline Nilai Terrendah & & 68 & & 69 & \\
\hline
\end{tabular}

Berdasarkan tabel 7 nilai yang dari siklus I dan siklus II menunjukkan adanya peningkatan. Pada siklus I tidak ada satupun siswa yang berada pada rentang nilai $0-25$ dan 26-50, siswa yang memperoleh rentang nilai 51-75 berjumlah 24 siswa atau sebanyak 63\%, sedangkan siswa yang memperoleh rentang nilai 76-100 berjumlah 14 siswa atau sebanyak $37 \%$ dengan ratarata kelas 75.86 dari total keseluruhaan 38 siswa. Pada siklus II mengalami peningkatan yaitu tidak ada satupun siswa yang berada pada rentang nilai $0-25$ dan 26-50 sama seperti pada siklus I, siswa yang memperoleh rentang nilai $51-75$ berjumlah 1 siswa atau sebanyak 3\%, sedangkan siswa yang memperoleh rentang nilai 76-100 berjumlah 37 atau sebanyak $97 \%$ dengan rata-rata kelas 79.14. peningkatan hasil belajar siswa siklus I dan siklus II pada dapat diperjelas melalui gambar 4.

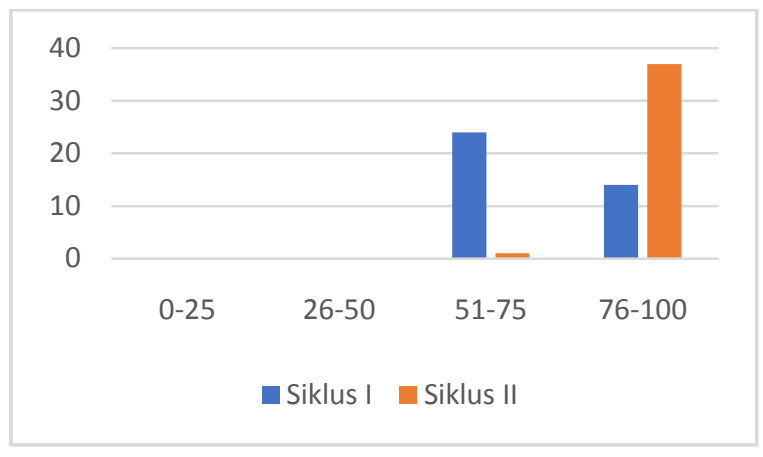

Gambar 4 . Grafik Peningkatan Hasil BelajarSiswa Siklus Idan Siklus II

\section{Pembahasan}

Melalui penerapan model pembelajaran Group To Group Exchange (GGE) pada pembelajaran Tema 7 Indahnya Keragaman di Negeriku pada siswa kelas 4 SDN Mangunsari 03 dengan jumlah siswa 38 , berdasarkan hasil angket dan tes evaluasi yanag sudah dilakukan mengalami peningkatan dibandingkan dengan pra siklus yang belum menerapkan model pembelajaran Group To Group Exchange (GGE), kemudian setelah diterapkannya model pembelajaran $G G E$ pada pembelajaran siklus I dan siklus II.

Penerapan model pembelajaran ini siswa dalam kelompok diberikan materi atau topik yang berbeda dan membuat rumusan 
masalah, kemudian siswa dalam kelompok diminta mencari, mengumpulkan informasi dari berbagai sumber, dan mengolah informasi yang sudah diperoleh melalui diskusi kelompok, kemudian siswa bekerja sama menyusun bahan untuk presentasi, melalui presentasi siswa melakukan tanya jawab, tukar informasi, dan berpendapat.

Peran guru sangat penting dalam pembelajaran, peningkatan aktvitas guru akan berpengaruh terhadap peningkatan aktivitas siswa pada setiap siklusnya. Guru membimbing, mengarahkan dan mendorong siswa agar aktif dan meningkatkan kemampuan comunicating siswa. Pada siklus I Berdasarkan pembelajaran yang telah dilaksanakan selama 3 hari berturut-turut, kemampuan comunicating siswa kelas 4 mengalami peningkatan yang berdampak pada peningkatan hasil belajar siswa. Pada siklus I ini masih terdapat kelemahan baik dari guru dan peneliti maupun siswa. Dalam proses pembelajaran yang terjadi beberapa kekurangan dari guru adalah kurang mampunya mengendalikan siswa terlihat dari aktifitas siswa yang masih gaduh, kurang mampu mendorong siswa untuk bertanya menjawab dan mengemukakan pendapat, guru juga kurang memberikan teguran bagi siswa yang masih diam tidak mau iku andil dalam presentasi.

Berdasarkan hasil angket kemampuan comunicating siswa pada siklus I menunjukkan pada kriteria kurang baik masih terdapat 18 siswa atau $47 \%$, pada kriteria cukup terdapat 19 siswa atau $50 \%$ dan yang menempati kriteria baik hanya 1 siswa atau sebesar 3\% saja dari total keseluruhan 38 siswa atau dalam persentase maksimal $100 \%$ pada kemampuan comunicating. Skor nilai kemampuan comunicating pada siklus I ini menunjukkan nilai terrendah 51, nilai tertinggi 68 dengan rata-rata 59.31.

Kemampuan comunicating siswa pada siklus I diperoleh hasil tidak ada satupun siswa yang berada pada rentang nilai 0-22 dan 26-50, sebanyak 24 siswa yang berada pada rentang nilai 51-75 atau sebanyak 63\% dan siswa yang mampu mencapai rentang nilai 76100 sebanyak 4 siswa atau sebesar $37 \%$. Nilai pos tes dengan jumlah keseluruhan 38 siswa dengan KKM 75 mencapai rata-rata kelas 75.86 .

JIPP, Volume 2 Nomor 2 Juli 2018
Setelah memperoleh hasil kemampuan comunicating dan hasil belajar siswa pada siklus I peneliti menyusun rencana pelaksanaan siklus II. Pada siklus II sudah terlihat adanya perbaikan, guru dan peneliti lebih mengerti jalannya pembelajaran menggunakan model pembelajaran Group To Group Exchange, begitu pula dengan siswa mampu di atur menjadai tidak gaduh, siswa juga memperoleh bimbingan guru sehingga mampu mempresentasikan hasil kerjanya dan mampu bertanya, menjawab dan berpendapat. Siswa juga sudah terbiasa belajar dengan berkelompok, mengumpulkan informasi sendiri dan siswa semakin aktif berani bertanya, berpendapat dan presentasi.Seperti yang telah dilakukan pada siklus I pada akhir pertemuan siklus II siswa diberikan lembar angket dan soal evaluasi.

Kemampuan comunicating siswa pada siklus II ini mengalami peningkatan dibandingkan dengan siklus I, pada siklus II ini menunjukkan tidak terdapat satupun siswa yang berada dalam kriteria baik, pada kriteria sangat baik terdapat 38 siswa atau $100 \%$ atau semua siswa memperoleh kriteria sangat baik. Skor nilai kemampuan comunicating pada siklus II ini menunjukkan nilai terrendah 70 , nilai tertinggi 80 dengan rata-rata 75.8.

Sedangkan hasil belajar siswa pada siklus IImemperoleh hasil tidak ada satupun siswa yang berada pada rentang nilai 0-22 dan 26-50, sebanyak 1 siswa yang berada pada rentang nilai 51-75 atau sebesar 3\% dan siswa yang mampu mencapai rentang nilai 76-100 sebanyak 37 siswa atau sebesar 97\%. Pada siklus II ini nilai pos tes dengan jumlah keseluruhan 38 siswa dengan KKM 75 mencapai rata-rata kelas 79.14.

Peningkatankemampuan comunica-ting siswa kelas 4 SDN Mangunsari 03 dari siklus I ke siklus II sebesar 27\%. Begitupula hasil belajar siswa yang telah dilakukan pada siklus I persentase ketuntasan mencapai $76 \%$, pada siklus II mengalami kenaikan dengan persentase ketuntasan mencapai 97\% dari jumlah keseluruhan siswa tuntas lebih dari KKM 75.

Penelitian yang relevan yang dilakukan oleh Vina, T, A, Sutama, dan Samino (2014: 69)dengan judul Dampak Komunikasi Siswa Terhadap Hasil Belajar Matematika Sekolah Dasar, membuktikan bahwa kemampuan komunikasi siswa juga ber dampak pada hasil 
belajar matematika sekolah dasar dengan bantuan model pembelajaran TGT.

Dewi,Wiyasa2, Putra (2014: 1) membuktikan bahwa model Kooperatif tipe Group To Group exchange berbantuan media gambar lebih baik dari pada siswa yang belajar menggunakan model pembelajaran Kooperatif tipe STAD dilihat dari hasil belajar siswa pada penelitian eksperimen.

Efendi dan Safnowandi (2016: 42) melakukan penelitian tentang peningkatan keterampilan sosial dan hasil belajar kognitif siswa melalui model pembelajaran aktif tipe Group to Group Exchange pada jurnal pendidikan Mandala. Penelitian ini membuktikan bahwa model Group to Group Exchange mampu meningkatkan ke-mampuan kognitif siswa.

Berdasarkan beberapa penelitian di atas, maka dapat ditarik kesimpulan bahwa dalam meningkatkan kemampuan saintifik khususnya kemampuan comunicating, hasil belajar dan keterampilan lainnya dapat menerapkan model pembelajaran Group To Group Exchange atau model pembelajaran yang menuntut siswa belajar dalam kelompok, membuat siswa aktif, terampil dalam mengkomunikasikan apa yang sudah dipelajari sehingga dalam pembelajaran siswa mampu bertukar pendapat, informasi, diskusi dan memperoleh pengetahuan baru.

Sejalan dengan penelitiandiatas, penelitiaan ini juga membuktikan penerapan model $G G E$ tidak hanya mampu meningkatkan hasil belajar siswa namun melalui langkah-langkah, sumber belajar dan arahan guru kemampuan comunicating siswa juga mampu mengalami peningkatan.

\section{SIMPULAN DAN SARAN}

Penelitian Tindakan Kelas yang telah dilakukan di kelas 4 SDN Mangunsari 03 semester II tahun pelajaran 2017/2018 padatema 7 Indahnya Keragaman di Negeriku melalui penerapan model pembelajaran Group To Group Exchange (GGE)mampu meningkatkan kemampuan comunicating siswa.

Pada siklus I kemampuan comunicating siswa menunjukkan rata-rata skor 59.31 dan pada siklus II mengalami peningkatan menjadi 75.28. Dari siklus I ke siklus II melalui proses penghitungan diperoleh hasil peningkatan kemampuan comunicating siswa sebesar $27 \%$.

Adapun saran berdasarkan hasil penelitian yang telah dilakukan dan keterbatasan penelitian adalah Model pembelajaran Group To Group Exchange $(G G E)$ dapat digunakan sebagai salah satu model yang mampu meningkatkan kemampuan comunicating siswa yang berpengaruh pada peningkatan hasil belajar siswa. Sebaiknya guru lebih membimbing dan memotivasi siswa dalam belajar, sedangkan bagi siswa diharapkan lebih aktif untuk berbagi informasi dan pengetahuan pada saat pembelajaran, sehingga apa yang dipelajari siswa lebih dimengerti, bermakna sehingga kemampuan siswa dalam berdiskusi, bertanya dan berpendapat lebih diasah untuk memperoleh hasil yang baik.

\section{DAFTAR RUJUKAN}

Anggaraeni, V.T., Sutama, \& Samino. (2014). Dampak Komunikasi Siswa Terhadap Hasil Belajar Matematika Sekolah Dasar. Varia Pendidikan. 26 (1), 69-76.

Arikunto, S. (2010). Prosedur Penelitian: Suatu Pendekatan Praktik. Jakarta: Rineka Cipta.

Astuti, S, Slameto, \& Yari. (2017). Peningkatan Kemampuan Guru Sekolah Dasar dalam Menyusun Instrumen Ranah Sikap Melalui In Hous Training. Jurnal Kelola. 4 (1), 37-44.

Astuti, Suhandi. 2017. Supervisi Akademik Untuk Meningkatkan Kompetensi Guru Di SD Laboratorium UKSW. Scholaria. 7 (1), 49-59.

Dewi,E. Y., Wiyasa, I. N., \& Putra, D.S. (2014). Pengaruh Model Pembelajaran Group To Group Exchange Berbantuan Media Gambar Terhadap Hasil Belajar IPS Siswa Kelas IV SD Gugus II Tampaksiring. e-jurnal mimbar PGSD Universitas Pendidikan Ganesha. 2(1), 1-12.

Hutagalung, I. (2007). Pengembangan Kepribadian (Tinjauan Praktis Menuju Pribadi Positif). Jakarta: PT Macanan Jaya Cemerlang.

Iskandar. 2012. Penelitian Tindakan Kelas. Jakarta. Referensi (GP Press Group). 
Ismail, E, \& Sofnowandi. (2016). Peningkatan Keterampilan Sosial dan Hasil Belajar Kognitif Siswa Melalui Metode Belajar Aktif Tipe GGE (Group to Group Exchange). Jurnal Pendidikan Mandala, (1) 42-49.

Kurnia, I dan Wakhyudi. 2014. Evektivitas Model Think Pair Share dalam Pembelajaran Tematik Integratif Terhadap Kemampuan Pemecahan Masalah. Universitas PGRI Semarang. 4 (1), 57-66.

Mawardi, \& Sari, D. L. (2015). Keefektifan Model Pembelajaran Picture and Picture dan Make a Match Ditinjau dari Hasil Belajar dalam Pembelajaran IPA Kelas 4 SD Gugus Mawar-Suruh. Scholaria. 5 (3), 8299.

Murni, A., Yusra, N., Solfitri. (2010). Penerapan Model Belajar Aktif Tipe Group To Group Exchange (GGE) untuk Meningkatkan Hasil Belajar Matematika Kelas X IPS MAN 2 Model Pekanbaru. Jurnal Penelitian Pendidikan. 2 (11), 1-10.

Noviyanti, M. (2011). Pengaruh Motivasi dan Keterampilan Berkomunikasi Terhadap Prestasi Belajar Mahasiswa Pada Tutorial Ounline Berbasis pendekatan Kontekstual Pada Matakuliah Statistika Pendidikan. Jurnal FKIP-UT 12 (2), 80-88.

Prayogo dan Silviana, A. (2010). Upaya Meningkatkan Prestasi Belajar Matematika Siswa dengan Pembelajaran Aktif Menggunakan Strategi Group To Group Exchange Melalui Bantuan Tutor Sebaya di Kelas X SMA Muhammadiyah 5 Karanggeneng Lamongan. Jurnal Semnas. Pendidikan Matematika dan Statistika UNIPA. Surabaya.

Puspita,V.,\&Yuhelman,N.(2017).Peningkata $\mathrm{n}$ Proses Pembelajaran Tematik dengan Menggunakan PendekatanProblem BasedLearning diKelasIII SD.Pendidikandan Keguruan, VIIINo.

Rusman. (2012). Model-model

Pembelajaran. Depok:PT
Sardiman. (2011). Interaksi dan Motivasi Belajar Mengajar. Jakarta: PT Raja Grafindo Persada.

Silberman, Melvin. (2010). 101 Cara Pelatihan \& Pembelajaran Aktif. (Alih bahasa: Dani Dharyani). Jakarta: Indeks.

Soelaeman, M. 2007. Ilmu Budaya Dasar. Bandung: PT. Refika Aditama.

Sugiyono. 2010. Metode Penelitian Pendidikan Pendekatan Kuantitatif, Kualitatif dan $R \& D$. Bandung: Alfabeta.

Rajagrafindo Persada. 